\title{
CREB-Binding Protein
}

National Cancer Institute

\section{Source}

National Cancer Institute. CREB-Binding Protein. NCI Thesaurus. Code C17803.

CREB-binding protein (2442 aa, $\sim 265 \mathrm{kDa}$ ) is encoded by the human CREBBP gene. This protein is involved in the mediation of histone acetylation. 